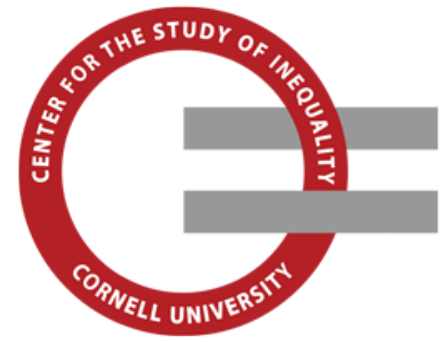

Center for the Study of Inequality Cornell University

363 Uris Hall

Ithaca, NY 14850

(607)254-8674

inequality@cornell.edu

www.inequality.cornell.edu

\title{
Conditional Status Quo Bias and Top Income Shares: How U.S. Political Institutions Have Benefited the Rich
}

\author{
Peter K. Enns \\ Cornell University \\ Nate Kelly \\ University of Tennessee \\ Jana Morgan \\ University of Tennessee \\ Thomas Volscho \\ CUNY-Staten Island \\ Chris Witko \\ University of South Carolina
}

Final version published as: Enns, Peter K., Nate Kelly, Jana Morgan, Thomas Volscho, and Chris Witko. 2014. "Conditional Status Quo Bias and Top Income Shares: How U.S. Political Institutions Have Benefited the Rich." Journal of Politics. 76(2): 1-15.

https://doi.org/10.1017/S0022381613001321

Copyright: (C) Southern Political Science Association, 2014. This publisher's version/PDF complies with publishers guidelines for institutional repositories.

This article is brought to you free and open access by the Center for the Study of Inequality Collectionin eCommons@cornell.edu.

Follow this and additional works at: https://ecommons.cornell.edu/handle/1813/52084 


\title{
Conditional Status Quo Bias and Top Income Shares: How U.S. Political Institutions Have Benefited the Rich
}

\author{
Peter K. Enns Cornell University \\ Nathan J. Kelly University of Tennessee \\ Jana Morgan University of Tennessee \\ Thomas Volscho CUNY-Staten Island \\ Christopher Witko University of South Carolina
}

\begin{abstract}
This article develops and tests a model of conditional status quo bias and American inequality. We find that institutional features that bias policy outcomes toward the status quo have played a central role in the path of inequality. Using time-series analysis of top income shares during the post-Depression period, we identify the Senate as a key actor in the politics of income inequality. Our findings suggest that the supermajoritarian nature of the Senate and policy stagnation, when coupled with economic and social factors that produce rising inequality, create a situation in which inequality becomes difficult to reverse.
\end{abstract}

E conomic inequality has been rising in the United States. ${ }^{1}$ This is no longer news. After a lull in sustained interest among scholars of American politics, questions about the causes and consequences of rising inequality have motivated a great deal of research in the past decade. One of the core conclusions emerging from this literature is that the politicians we elect and the policies they pursue have dramatic consequences for the relative well-being of the rich and the poor.

In this article, we move beyond explanations of inequality that are rooted in partisan control of institutions and specific policy choices, exploring how elements of the U.S. system that bias outcomes toward the status quo have contributed to the rise of the super-rich. We posit a theory of conditional status quo bias which argues that the relationship between U.S. policymaking institutions and top income shares is conditional on both ideological divergence across parties and past levels of inequality. Our results, based on a time-series analysis of nearly 70 years of U.S. income data, also suggest an explanation for why inequality has continued to rise despite increasing public concern regarding this outcome-enacting the policy changes needed to reverse the upward trend in the income gap has become increasingly difficult. ${ }^{2}$

The analysis discussed below enhances our understanding of American income inequality in three primary ways. First, we develop and test conditional status quo bias (CSQB) as a theoretical explanation for income concentration. A substantial comparative literature focuses on institutional design as an important correlate of economic inequality (Alesina and Glaeser 2004; Birchfield 2008; Huber, Ragin, and Stephens 1993; Stepan and Linz 2012). Recent research in American politics also points to a role for status quo bias, suggesting that as conditions change over time and policy does not, outcomes are likely to shift producing "policy drift" and opening the door for massive income growth at the top (Hacker and Pierson 2010; McCarty, Poole, and Rosenthal 2006). We accept the

\footnotetext{
${ }^{1}$ Support for this research was provided by the Russell Sage Foundation project 83-13-03. The views expressed herein are those of the authors and do not necessarily reflect the views of the Russell Sage Foundation. An online appendix with supplementary material for this article is available at http://dx.doi.org/10.1017/S0022381613001321. Data and supporting materials necessary to reproduce the numerical results will be made available at http://dvn.iq.harvard.edu/dvn/dv/nkellydata prior to publication.

${ }^{2}$ Of course, awareness and concern with rising inequality does not automatically translate into support for more redistributive policy preferences (Bartels 2008; Kelly and Enns 2010).
} 
idea that several aspects of U.S. institutional design correspond with economic inequality, but we contend that these institutional factors become relevant only when ideological disagreement across parties and institutions is sufficient to elevate the likelihood of gridlock. In addition, we argue that these institutional effects are more inequality-inducing when past levels of inequality have been driven sufficiently high by other political, economic, and social factors, meaning that the trajectory of inequality is difficult to reverse in an institutional context where policy change is difficult.

Second, testing the CSQB argument also allows us to bring together two major traditions of work in the area of U.S. income inequality. One research tradition has emphasized the influence of legislative/executive partisanship and the ideological content of policymaking (Bartels 2008; Hacker and Pierson 2010; Kelly 2009). For example, Kelly (2009) and Bartels (2008) focus on partisan politics, arguing that Democratic presidents have generated lower levels of economic inequality during the post-WWII period than Republicans. Hacker and Pierson (2010) focus on the role of elite ideology, policy, and group-based politics. In their account, rising inequality has been driven by a rightward shift in American politics that originates in the increasing influence of business and the declining influence of unions in the political process. In contrast to research on the ideological leanings of government and policy, a second line of scholarship has focused on explaining the dearth of policies that promote redistribution (even to the middle class) despite rising inequality (Hacker and Pierson 2010; McCarty, Poole, and Rosenthal 2006). We are among the first to explicitly examine explanations from both of these main traditions in a quantitative study.

Finally, we provide a quantitative test of policy drift, an idea that has been derived and tested almost entirely in the context of qualitative analysis (Hacker et al. 2004; Hacker and Pierson 2010). Our analysis of CSQB and economic inequality provides the opportunity to specify some quantitative implications of the theory of policy drift. Specifically, we discuss how the likelihood of policy drift in the context of American political institutions has changed over time and examine how shifts in policy drift are associated with variation in income inequality over time.

\section{American Institutions and Economic Inequality}

The heart of our theory is that the status quo bias in American policymaking plays an important role in distributional outcomes. Our basic argument is as follows: a variety of economic, demographic, and political factors have created the conditions necessary for rising inequality. Without policy action, these conditions translate into more income concentration. But due to the status quo bias inherent in the U.S. political system, such policy action is rendered unlikely. Moreover, hurdles to policymaking exacerbate inequality to a greater extent as the gap between the rich and the poor grows. That is, the inequalityinducing effect of bias toward the status quo in U.S. policymaking is enhanced as inequality rises and is diminished as inequality declines. ${ }^{3}$

Observers of American politics are familiar with many of the factors that make policy action difficult in the U.S. system. Separated powers along with a bicameral legislature generate multiple veto points. Where veto points abound, policymaking is more difficult because actors in a wider range of institutions must come to agreement before policy change can occur (Brady and Volden 1998; Krehbiel 1998). Unlike a parliamentary system, where decisions taken by the government are sufficient to enact change, in the United States at least a majority in two separate chambers of the legislature as well as the president must come to agreement in order to produce dramatic policy change through the lawmaking process. Having control of even just the House of Representatives presents a political party with the ability, under some conditions, to dramatically influence the policymaking process, particularly by shaping which status quo policies are protected and which policies are part of the policy change agenda (Cox and McCubbins 2005b; Finocchiaro and Rohde 2008; Krehbiel 1998; Richman

\footnotetext{
${ }^{3} \mathrm{We}$ see two possible processes that could connect policy stagnation to rising inequality. The first is a primarily economic process, in which rising inequality increases opportunities for the super-rich to use their economic power to enhance their wellbeing. For example, the increased concentration of wealth implies the super-rich have more capital to invest, more favorable investment opportunities, and enhanced ability to outwait unfavorable market conditions. Without regulatory interventions, increasing opportunities for such monopoly-like gains increase unabated, thereby generating higher levels of inequality. The other process is more squarely in the political realm. Rising inequality might place the rich at an advantage in the democratic process, making it possible for them to consolidate power and increase their relative status through politics (Bartels 2008; Gilens 2012; Hacker and Pierson 2010; Pierson 2000). If either or both of these processes are at work, rising inequality becomes very difficult to reverse as ever more drastic policy action would be needed to undo the inegalitarian forces at work in the American economy. It is possible, of course, that the effect of factors connected to status quo bias is constant over time. If status quo bias is simply one among many "constant causes," we might observe a relationship between status quo bias and inequality, but this relationship would not vary with past levels of inequality.
} 
2011). Enhancing the difficulty of achieving policy action is the fact that actors in the House, Senate, and presidency are serving divergent constituencies-the president with a national constituency, Senators elected by states, and members of the House from much smaller districts within states. Finally, the comparative lack of party discipline (relative to parliaments) and numerous access points in the U.S. policymaking system provide a high degree of influence for interest groups, which tend to be particularly adept at stopping legislation contrary to their goals (Gilens 2012; Hacker and Pierson 2010). ${ }^{4}$

Within this system of separated powers, the Senate has unique characteristics that further heighten bias toward the status quo (Binder 2003; Wawro and Schickler 2006). Most generally, the Senate is designed to protect the rights of the minority and even of individual members. In the modern Senate, requiring 60 votes to pass legislation has essentially become the norm. This, of course, is due to the often discussed presence of the filibuster. It should also be noted that there are numerous other rules and norms in the Senate designed to protect the rights of individual members, including holds on nominations, open procedures for amending legislation on the floor, and the common need for unanimous consent in order to move forward on Senate business. All of this makes policy change difficult and in some ways places Senate (in)action at the core of the U.S. policy process.

How does this status quo bias relate to income inequality? As economies change and societies evolve in ways that enhance the possibility of gains for those at the top, policy must adapt in order to counteract increases in inequality (Hacker and Pierson 2010). However, redistributional policy action is much more difficult where institutions are strongly biased toward the status quo (Alesina and Glaeser 2004; Birchfield 2008; Huber, Ragin, and Stephens 1993; Huber and Stephens 2001; Stepan and Linz 2012; Tsebelis 2002). A theory of status quo bias would predict higher inequality in contexts where policy change is rendered more difficult and government is therefore less responsive to changing economic conditions generally and rising inequality specifically. There is some crossnational evidence in line with this expectation. While

\footnotetext{
${ }^{4}$ Our theoretical focus is status quo bias and policy inaction. We should note, however, that we also consider the role of policy action since several recent studies have found that partisan control of policymaking institutions and a variety of specific policies help to explain the path of income inequality over time (Bartels 2008; Kelly 2009; Kelly and Witko 2012; TomaskovicDevey and Lin 2011; Volscho and Kelly 2012).
}

most developed countries have faced economic changes that have heightened inequality over the past few decades, some have seen inequality increase more than others. Previous research suggests that where there are fewer (competitive) veto players and policymaking is somewhat less difficult, increases in inequality have been more limited than in countries where there are more (competitive) veto players and policy action is therefore more complicated (Crepaz 2001; Huber and Stephens 2006; Stepan and Linz 2012). Other studies have addressed the general phenomenon of status quo bias and the conditions under which specific policies become part of the legislative agenda (Baumgartner and Jones 2010; Cox and McCubbins 2005b; Finocchiaro and Rohde 2008; Gailmard and Jenkins 2007; McCubbins and Schwartz 1984). However, this article offers the first direct test of the extent to which status quo biasing institutions help explain the widening gap between rich and poor in the United States.

Moreover, the theory of conditional status quo bias that we test here adds an important new insight to our understanding of the relationship between institutional structure and inequality. Our argument is that the effect of status quo bias varies depending on the existing level of inequality, with status quo bias magnifying existing inequities more when societies are already experiencing high inequality. If inequality is low and economic conditions are not pushing inequality higher, a bias toward the status quo in policymaking is unlikely to produce rising inequality. While it may be the case that stagnation in certain policy areas has the potential to increase inequality over time regardless of the existing gap between the rich and the poor (Hacker and Pierson 2010), major policy change is likely unnecessary to keep inequality relatively low when economic conditions are not inclined to widen inequality. On the other hand, when economic conditions are producing high levels of inequality, this is precisely the time when dramatic policy action is needed if rising inequality is to be prevented. In this situation, status quo bias would enable substantial increases in inequality. This leads us to predict that the effect of status quo bias on rising inequality will become greater as the existing level of inequality increases.

But how can enduring institutions explain varying levels of inequality? Our answer is that the practical relevance of status quo bias in institutional design is shaped by politico-economic circumstances. Consider veto points. Although the number of checks on policymaking has not changed in the post-WWII era, the relevance of these veto points has varied over time. If the House, Senate, and 
President are all in agreement, the fact that there are so many veto players is less relevant than when these three players are at odds ideologically (Krehbiel 1998). If the veto players argument helps explain rising inequality, then there should be a positive association between preference divergence across the veto points and income inequality. If, in addition, the theory of conditional status quo bias is correct, the effect of preference divergence on inequality should become stronger and more positive as the gap between the rich and the poor increases.

The eccentricities of the Senate can also be translated appropriately into a crosstemporal context in order to produce predictions regarding inequality. First, if Stepan and Linz, (2012) are correct that the Senate has more explicit power than the House, any partisan or ideological effects (discussed below) should be magnified in the Senate. Second, given the important role of the filibuster in the Senate, if we are correct that policy stagnation exacerbates inequality, then as the ideological distance between the median Senator and the filibuster-pivot increases, inequality should increase as well. In addition, the conditional component of our theory predicts that the inequalityinducing effect of preference divergence within the Senate should grow as inequality increases.

\section{Data and Measurement}

Dependent Variable. The dependent variable in our analysis is the annual share of aggregate pretax, pretransfer income held by the top 1\% from 1940 to 2006. ${ }^{5}$ Our data are from the Piketty and Saez (2003)

\footnotetext{
${ }^{5} \mathrm{We}$ elected to focus on this time period for a combination of theoretical and practical reasons. Theoretically, the 1940-2006 period allows us to analyze both a long period of income compression and the more recent income divergence. Focusing on this period also allows us to examine a period bracketed by the two largest economic crises in U.S. history. We believe this is important because it is likely that different economic and political processes are at work during financial crises, especially during the Great Depression. In particular, a Congress-centric theory such as ours is unlikely to be operative during the period when the FDR administration-because of the Great Depression-was taking unprecedented steps to control the legislative process and shift power away from Congress (Katznelson 2013). Practically, the start of our analysis is limited by the lack of available data (including an essential control variable measuring the importance of the financial sector to the U.S. economy). However, to explore our expectations about the applicability of our model in different periods, we reestimated models including only status quo bias variables for various time periods. We found that the results are consistent with those reported below for periods starting after the Great Depression. However, consistent with expectations, the effects of status quo bias are suppressed when we analyze the Great Depression.
}

top income-shares dataset (see http://elsa.berkeley. $\mathrm{edu} / \sim$ saez/TabFig2008.xls) which is based on an analysis of Internal Revenue Service tax documents. This is widely regarded as the best source for assessing incomes of very rich individuals, as is our goal here. ${ }^{6}$

But why analyze pretax, pretransfer income? One might suspect that limiting analysis to pretax/transfer inequality excludes a role for politics and policy. To the contrary, government has many ways to potentially condition the market (Hacker and Pierson 2010; Kelly 2009; Morgan and Kelly 2013). Nearly every action that government takes can change the market incentives of organizations and individuals. When economic actors respond to government-induced changes in incentives, the effects of these government actions will most often be observed in the market. Financial deregulation opened the door to ever more inventive financial instruments, likely producing an increase in market inequality (Tomaskovic-Devey and Lin 2011). Tax policies affect wages, labor market, and consumer behavior. For example, a reduction in taxes on capital gains introduces an incentive to shift income from wages to capital gains. Since the very rich receive large portions of income from capital gains, such a move is likely to generate higher levels of market inequality (Slemrod 1996; Volscho and Kelly 2012). Labor-market regulations affect wages, benefits, and the power of unions. Monetary policy in the form of interest rates affects the cost of borrowing. Some previous work has concluded that the super-rich benefit from low interest rates because, as bond-holders, the value of those bonds increases as the interest rate decreases thereby enhancing the opportunity for capital gains income (Canterbery 2002; Henwood 1997; Volscho and Kelly 2012). In short, almost everything government does has the capacity to alter private economic decisions at the margin, which can in turn contribute directly or indirectly to income inequality. In fact, one of the central arguments made by Hacker and Pierson (2010) and Kelly (2009) is that government redistribution (which would be captured in post-tax/transfer income) is not necessarily the

\footnotetext{
${ }^{6}$ The Piketty and Saez (2003) data do not require top-coding the incomes of the super-rich, which is an important step forward in measurement. All income data in this article refer to Piketty and Saez's series inclusive of realized capital gains. We utilize an income concept inclusive of capital gains because it is the most comprehensive income concept available and captures an extremely important component of income for the super-rich.
} 
primary mechanism through which the government shapes distributional outcomes. ${ }^{7}$

\section{Explanatory Variables}

Institutionalized status quo bias. Given our focus on the role of CSQB in contributing to rising inequality, we consider three variables to assess different facets of institutional design and status quo bias. First, we include a measure of the distance between the filibuster pivot and the Senate median (Senate Median to Filibuster Pivot Distance) based on Common Space DW-NOMINATE scores (Carroll et al. 2011). These scores provide a measure of the ideological preference of members of Congress and presidents since 1940 in a common ideological space based on roll call voting behavior in Congress and public positions of the president.

Using these scores for the Senate, we identify the filibuster pivot, which is the ideological score of the Senator whose vote is required to obtain cloture. For each year, we identify the relevant Senator by arranging the Senate from left to right in ideological space based on DW-NOMINATE scores. When Democrats are in the majority, the filibuster pivot is the Senator who is more conservative than 59 other Senators. When Republicans are in power, the filibuster pivot is the Senator more liberal than 59 others. ${ }^{8}$ As the distance between the median and filibuster pivot widens, the relevance of the Senate's unique institutional rules concerning cloture increases. This measure is independent of partisanship, capturing the propensity for policy stagnation due to ideological differences in the supermajoritarian Senate. We expect the median-filibuster-pivot distance to

\footnotetext{
${ }^{7}$ Ideally, we could examine changes in both pretransfer and posttransfer inequality in order to assess the distributional impact of the state via the market and explicit redistribution. But since our goal here is to study the level of inequality produced by the market, the Piketty and Saez (2003) data are appropriate. Additionally, posttransfer data that accounts for the incomes of the very rich are not yet available over a long period of time. Therefore, we restrict our analysis to pretax, pretransfer top income shares.

${ }^{8}$ Prior to 1975,67 votes were required for cloture, so our measure is adjusted accordingly for these years.
}

be associated with higher levels of income concentration. ${ }^{9}$

Our second measure of institutional status quo bias, also built using Common Space DW-NOMINATE scores, is designed to capture changes in the relevance of multiple veto points. We calculate the distance between the House median and Senate median, House median and president, Senate median and president, and Senate median and filibuster pivot. We then take the absolute value of the largest distance as an indicator of maximum preference divergence across the main policymaking actors (Maximum Preference Distance). As preference divergence increases, the presence of multiple veto points becomes more problematic for policymaking. If the presence of multiple veto points has played a role in allowing rising inequality to go unchecked, we should see a positive association between interinstitutional distance and top income share.

Third, we include a measure that explicitly captures the amount of policy produced by Congress. This measure, which was originally developed by Grant and Kelly, (2008), is based on a combination of important and general lawmaking (Congressional Policy Product). It measures overall legislative production during each Congress and taps the idea of policy stagnation. When less policy is being made, we expect to observe increased inequality. ${ }^{10}$

To test our conditional hypothesis-i.e., the effects of institutionalized status quo bias are more inequality -inducing when existing levels of inequality

\footnotetext{
${ }^{9}$ Our focus on preference divergence in the Senate places ideological polarization at the center of the story regarding the use of the filibuster in the Senate. It is also, clear, however, that changing norms have contributed to the increasing use of filibusters (Binder and Smith 1997; Koger 2010; Wawro and Schickler 2006). In a supplemental information (SI) file, we report additional models that attempt to capture the role of norms as opposed to preference divergence in the Senate. In these supplemental models, we include the number of cloture motions filed. While the actual use of the filibuster is surprisingly difficult to capture empirically, cloture motions are often cited as a key indicator. We find that the results reported below remain essentially unchanged with controls for cloture motions and that cloture motions have a much weaker effect on inequality than the filibuster-pivot distance variable described above.

${ }^{10}$ In the Supporting Information, we also present an analysis in which Congressional Policy Product is modeled as a variable intervening between the indicators of status quo bias and inequality. This accounts for the fact that the models below capture only the direct effects of status quo bias on inequality and ignores any potential indirect effects that occur via reductions in legislative output. The implications for our analysis below remain unchanged. However, not surprisingly, we find that higher levels of house polarization are significantly related to lower levels of Congressional Policy Product. This result implies that house polarization also indirectly influences top income shares via the resulting reduction in policy activity.
} 
are high - the three measures are interacted with prior levels of inequality. These interaction terms allow a direct test of the hypothesis that rising inequality (whether caused by economic factors, political factors, or both) will be more likely to persist as status quo bias increases.

Party polarization. We include the ideological distance between the median member of the majority and minority parties in the House to account for general partisan polarization (House Party Polarization). Though clearly connected to the idea of policy stagnation, general polarization is not a feature of institutional design as much as it is an indicator of current political conditions. Thus, we are most interested in this variable in order to ensure that any effects connected to the unique features of U.S. institutional structures are not simply generated by overall patterns of partisan polarization (McCarty, Poole, and Rosenthal 2006). ${ }^{11}$ This measure is based on the previously discussed Common Space DW-NOMINATE scores. We also interact this variable with prior levels of inequality in order to control for any conditional effects of general polarization.

\section{Partisan and Policy Controls}

Partisan politics, in the form of party control of the presidency and/or Congress, plays prominently in several analyses of income inequality (Bartels 2008; Campbell 2011; Hibbs and Dennis 1988; Kelly 2009; Kenworthy 2010). Democrats, as the party more strongly supported by middle- and working-class voters, have a strong electoral incentive to support programs to reduce inequality. Republicans, who receive more of their support from the upper end of the income distribution, are often eager to enact upwardly redistributive policy interventions. It is

\footnotetext{
${ }^{11}$ In other words, general party polarization itself would not be expected to have particularly unique effects in the American context. Factors related to interinstitutional disagreement and the supermajoritarian nature of the Senate, described above, are the relevant variables for testing our theory of CSQB and inequality in the United States. Of course the three measures of status quo bias we discuss are empirically related to ideological polarization. In the Supporting Information, we discuss the distinctiveness of status quo bias measures from general polarization and estimate additional models that address potential questions about collinearity between the measures of status quo bias and general polarization. Consistent with the results reported below, the supplemental analysis suggests that measures of status quo bias, though they are related to general polarization, are more effective explanations of income inequality over time than general polarization. We believe this is largely due to the fact that focusing on status quo bias accounts for how ideological divides play out in the institutional structure of U.S. government, particularly the important role of the Senate.
}

essential to control for partisan and ideological explanations of inequality in order to accurately assess the effects of variables connected to status quo bias. We thus incorporate two measures reflecting party control in Congress: party control of the Senate, and party control of the House, which are coded 1 when Democrats maintain a majority and 0 when Republicans are in control. ${ }^{12}$

We also consider the effects of monetary, tax, and regulatory policies on distributional outcomes. Despite the fact that our focus is status quo bias and policy inaction, it is clear from other recent studies of American income inequality that much of the policy action, at least since the 1970s, has contributed to rising inequality. Higher interest rates have been shown to reduce top income shares (Volscho and Kelly 2012), and we include this measure of monetary policy in our analysis. Despite the fact that our dependent variable is measured on a pretax basis, tax policy might also influence top income shares by influencing labormarket effort or by incentivizing income shifting across time or income sources. We consider two tax-policy measures. First, we include the top marginal incometax rate since this is the rate most likely to affect the earned income of the top $1 \% .{ }^{13}$ Second, we include the top capital-gains rate. Since those in the top $1 \%$ receive large amounts of income in the form of capital gains, changes to this area of tax policy are likely to influence top income shares. ${ }^{14}$ Finally, we include a measure of financial deregulation Philippon and Reshef (2012) with the expectation that deregulation will enhance top income shares.

\section{Socioeconomic Control Variables}

We also include variables controlling for three particularly important aspects of the general social-economic context that are likely relevant for understanding the rise of top income shares - union strength, financialization, and economic growth.

Decline of Unions. Union strength is a central aspect of several theories of income inequality. Strong unions give greater bargaining power to labor versus capital and redistribute wages downward

\footnotetext{
${ }^{12}$ We also considered variables connected to the ideology rather than the partisanship of Congress, and the results vary only slightly (see Table 4 in the Supporting Information).
} 
(Bradley et al. 2003; Hicks 1999; Huber and Stephens 2001; Korpi 1978; Moller et al. 2003; Stephens 1979). We include a measure of union density to control for the strength of unions in the U.S. economy (Hirsch 2008).

Financialization. Financial transactions have increased dramatically in their complexity and profitability. Financialization-the growing importance of financial markets and institutions for economic outcomes-has expanded notably in the U.S. economy (Krippner 2011). This process, which is likely due in part to regulatory policy changes, could generate rising inequality due to the shift of income and profits toward this relatively wealthy economic sector (Demenil and Levy 2004; Kaplan and Rauh 2010; Tomaskovic-Devey and Lin 2011). We capture the concept of financialization by measuring financial sector profits as percentage of GDP. The data are provided by the Bureau of Economic Analysis (2012).

Economic growth. Finally, we include GDP per capita in constant 2005 dollars in our analysis to control for general economic conditions and to account for opportunities for significant income gains among the rich.

\section{Methods}

We model top income shares using single equation error correction models (ECMs). Many of the variables in our analysis are nonstationary, and ECMs can avoid the risk of spurious regression results when estimating relationships between nonstationary variables (Banerjee et al. 1993; Engle and Granger 1987). We report tests of stationarity and integration in the Supporting Information file, which shows that most of our variables are clearly integrated. We also report tests to confirm that cointegration is present between our integrated dependent variable and the integrated explanatory variables, a step which is necessary to ensure that the ECM is an appropriate solution to the spurious regression problem. ${ }^{15}$ Based on these assessments, an ECM is an appropriate way to estimate relationships between the variables included in our analysis.

\footnotetext{
${ }^{15}$ Specifically, we establish cointegration with an augmented Engle-Granger test (Davidson and MacKinnon 1993, 720-21), which requires regressing top income shares on the predictors, performing an Augmented Dickey Fuller test on the residuals, and finally comparing the resulting test statistic to the corresponding critical value. Additionally, weak exogeneity is established following Charemza and Deadman (1992, 231-32); that is, the error-correction mechanism is insignificant when included in models of each of the predictor variables.
}

ECMs also allow an assessment of both immediate effects and effects that are distributed over time. In our analysis, for example, it is possible that a shift in tax policy produces an immediate effect on top income shares. But it is also possible that the effect of a taxpolicy change is not fully realized immediately. It is likely, in fact, that income responds to changes in tax policy over a period of years through a partialadjustment process. In a partial-adjustment process, a change in tax policy would shift the equilibrium top income share, and top shares would gradually move toward that new equilibrium value over time. In fact, for most of the variables in our analysis, we expect most if not all of the impact to be distributed over time. Generally speaking, the political, social, and economic factors that most likely explain the path of top income shares over time are thus likely to exhibit a long-run relationship. Nevertheless, the methodology we use allows us to capture both short- and long-run effects. ${ }^{16}$

Moving on to the nuts and bolts of an ECM model and how to interpret it, we begin with the bivariate equation version of the ECM:

$$
\Delta Y_{t}=\alpha_{0}+\alpha_{1} Y_{t-1}+\beta_{1} \Delta X_{t}+\beta_{2} X_{t-1}+\varepsilon_{t} .
$$

For each independent variable $X$, we have up to two parameter estimates $-\beta_{1}$ for the differenced variable, or its change from one point in time to the next, and $\beta_{2}$ for the lagged level of the variable, which can be dropped from the equation if we find that it has no statistically significant impact. $\beta_{1}$ provides an estimate of the initial change in the dependent variable produced in the short term by a shock to the independent variable. We call this the immediate effect. $\beta_{2}$ and $\alpha_{1}$ provide the information needed to estimate the "long-term" effect. This is also called the errorcorrection component of the model. The long-term impact is the portion of the connection between $X$ and $Y$ that does not occur at one particular point in time but is distributed temporally such that a portion of the impact is felt in each period over a time span. The size of this long-run impact is a function not only of $\beta_{2}$ but also of $\alpha_{1}$, which is known as the

\footnotetext{
${ }^{16}$ All of our models were initially estimated with Ordinary Least Squares. However, if a Breusch-Godfrey test indicated residual autocorrelation, we reestimated the model using Prais-Winsten regression, which is an appropriate strategy to correct autocorrelation in time-series models including the lagged level of the outcome variable (Keele and Kelly 2006). The results of our core models are similar without a correction for autocorrelation (see Table 4 in the Supporting Information) indicating that our results are not sensitive to this estimation choice.
} 


\section{Figure 1 Top Income Shares and Status Quo Bias, 1940-2006}

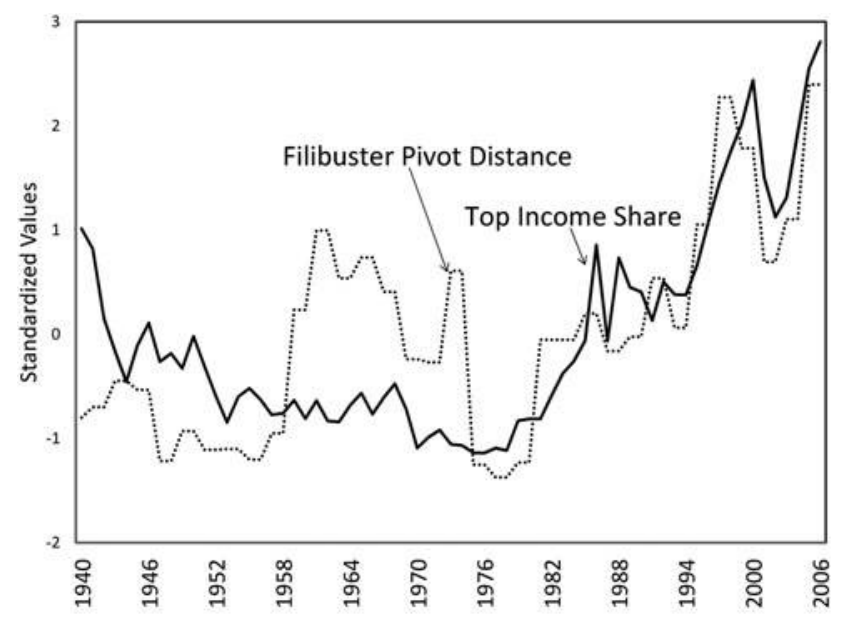

(a) Filibuster-Pivot Distance

error-correction rate. The total long-term impact of a shock to $X$ on $Y$ via the error-correction component, the long-run multiplier, is computed by dividing $\beta_{2}$ by $\alpha_{1}$.

Aside from being a component in the computation of an explanatory variable's impact, the error correction rate also tells us how quickly a disturbance from longrun equilibrium is eliminated. Estimates of $\alpha_{1}$ will be between 0.0 and -1.0 , and the closer this parameter is to -1.0 , the more quickly errors are corrected. The substantive interpretation of the coefficient is the proportion of the disequilibrium corrected in each time period, beginning at $t+1$. From this error-correction rate, we can determine how quickly the total long-run impact is felt.

\section{Analysis}

We begin our analysis in Figure 1 with a very simple plot of top income shares along with two of our key indicators of status quo bias-filibuster-pivot distance and Congressional Policy Product. For the purposes of the figure, we standardize all three measures so that they appear on a similar scale. We also invert the scale of Congressional Policy Product so that more positive values indicate less policy output. This aids the visual presentation so that we can expect a positive association with the three variables over time. And that is exactly what we observe. Particularly as inequality has risen since the 1970s, we observe an increase in filibuster-pivot distance and an increase in policy stagnation. In the late 1950s into the 1960s, there is some divergence between filibuster-pivot distance and top income shares, but this is exactly what our theory of CSQB would predict. Since inequality was

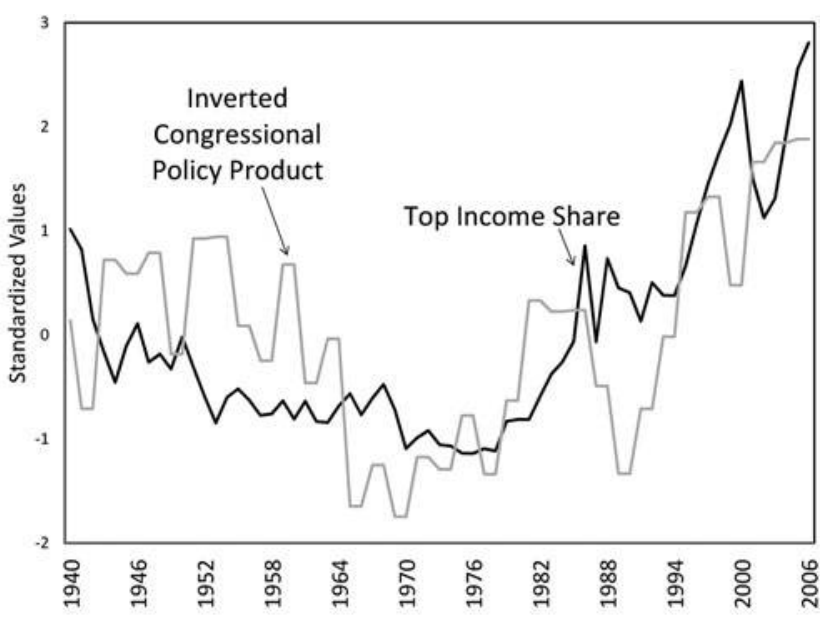

(b) Inverted Congressional Policy Product

low during this period, status quo bias is less likely to contribute to rising inequality. But this simple visual inspection is just a first step. In the more rigorous analysis reported below, we begin with simplified models focusing only on factors related to the theory of CSQB. We then move on to more fully specified models that consider other explanations. The heart of our analysis is presented in Table 1.

Model 1 includes three variables capturing institutional aspects of the U.S. system related to status quo bias-Senate Median to Filibuster-Pivot Distance, Maximum Preference Distance, and Congressional Policy Product. We also include House Party Polarization since we want to guard against any filibuster-pivot effect being driven by general patterns of party polarization. These variables only capture the direct effect of status quo bias variables on inequality. A second aspect of the theory is that the effect of institutional bias toward the status quo will become more important as inequality rises. That is, as income concentration increases, the effect of institutional factors related to status quo bias will become even more inequality inducing. We expect to observe this pattern because greater levels of inequality require greater policy action to reverse. If institutional factors activate status quo bias in this context, policymaking stagnates, allowing inequality to increase unchecked, heightening the inegalitarian bias in the system. We test these ideas with multiplicative interaction terms between the lagged level of income inequality and the lagged level of the three institutionalized status quo bias variables as well as party polarization. We construct the interaction terms using the lagged levels of the status quo bias variables because the 
TABLE 1 Models of Top Income Shares

\begin{tabular}{|c|c|c|c|c|c|}
\hline & (1) & (2) & (3) & (4) & (5) \\
\hline Top 1\% Share, Including Capital Gains $s_{t-1}$ & $\begin{array}{l}-0.18^{\star * \star} \\
(0.05)\end{array}$ & $\begin{array}{l}-0.16^{* * *} \\
(0.06)\end{array}$ & $\begin{array}{l}-0.43^{* * *} \\
(0.09)\end{array}$ & $\begin{array}{l}-0.17^{\star} \\
(0.09)\end{array}$ & $\begin{array}{l}-0.19^{\star * \star} \\
(0.05)\end{array}$ \\
\hline$\Delta$ Senate Median to Filibuster Pivot Distance ${ }_{t}$ & $\begin{array}{c}6.77^{\star} \\
(3.66)\end{array}$ & $\begin{array}{c}5.45 \\
(3.93)\end{array}$ & $\begin{array}{c}7.17^{\star} \\
(3.92)\end{array}$ & $\begin{array}{c}7.03^{\star} \\
(4.07)\end{array}$ & $\begin{array}{l}8.57^{\star *} \\
(3.58)\end{array}$ \\
\hline Senate Median to Filibuster Pivot Distance $_{t-1}$ & $\begin{array}{l}8.16^{* * *} \\
(2.80)\end{array}$ & $\begin{array}{r}6.14^{*} \\
(3.28)\end{array}$ & $\begin{array}{c}6.18 \\
(4.80)\end{array}$ & $\begin{array}{l}9.12^{* * *} \\
(3.32)\end{array}$ & $\begin{array}{l}7.71^{* * *} \\
(2.74)\end{array}$ \\
\hline$\Delta$ Maximum Preference Distance $_{t}$ & $\begin{array}{l}-0.17 \\
(0.88)\end{array}$ & $\begin{array}{l}-0.52 \\
(0.92)\end{array}$ & $\begin{array}{c}0.80 \\
(0.91)\end{array}$ & $\begin{array}{l}-0.10 \\
(1.35)\end{array}$ & \\
\hline 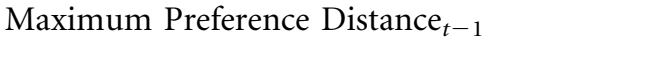 & $\begin{array}{c}0.09 \\
(0.70)\end{array}$ & $\begin{array}{l}-0.28 \\
(0.81)\end{array}$ & $\begin{array}{l}-0.81 \\
(0.91)\end{array}$ & $\begin{array}{l}-0.13 \\
(1.06)\end{array}$ & \\
\hline$\Delta$ Congressional Policy Product $_{t}$ & $\begin{array}{c}0.01 \\
(0.02)\end{array}$ & $\begin{array}{c}0.01 \\
(0.02)\end{array}$ & $\begin{array}{c}0.01 \\
(0.02)\end{array}$ & $\begin{array}{c}0.01 \\
(0.02)\end{array}$ & \\
\hline Congressional Policy Product $_{t-1}$ & $\begin{array}{l}-0.04^{* * *} \\
(0.01)\end{array}$ & $\begin{array}{l}-0.02^{\star} \\
(0.01)\end{array}$ & $\begin{array}{l}-0.05^{\star \star} \\
(0.02)\end{array}$ & $\begin{array}{l}-0.05^{* * *} \\
(0.01)\end{array}$ & $\begin{array}{l}-0.04^{\star * *} \\
(0.01)\end{array}$ \\
\hline$\Delta$ House Party Polarization ${ }_{t}$ & $\begin{array}{c}9.22 \\
(6.02)\end{array}$ & $\begin{array}{c}7.32 \\
(6.81)\end{array}$ & $\begin{array}{c}2.20 \\
(6.02)\end{array}$ & $\begin{array}{c}6.95 \\
(7.64)\end{array}$ & \\
\hline House Party Polarization ${ }_{t-1}$ & $\begin{array}{c}4.02 \\
(2.55)\end{array}$ & $\begin{array}{c}4.02 \\
(2.74)\end{array}$ & $\begin{array}{c}1.62 \\
(3.99)\end{array}$ & $\begin{array}{c}0.02 \\
(5.96)\end{array}$ & $\begin{array}{l}4.43^{\star *} \\
(1.75)\end{array}$ \\
\hline Filibuster Distance $^{\star}$ Top Share $_{t-1}$ & $\begin{array}{l}1.75^{\star *} \\
(0.75)\end{array}$ & $\begin{array}{c}1.08 \\
(0.90)\end{array}$ & $\begin{array}{l}2.59^{\star *} \\
(1.04)\end{array}$ & $\begin{array}{c}1.95^{\star} \\
(0.98)\end{array}$ & $\begin{array}{c}1.48^{\star} \\
(0.74)\end{array}$ \\
\hline Maximum Distance ${ }^{\star}$ Top Share $_{t-1}$ & $\begin{array}{c}0.34 \\
(0.26)\end{array}$ & $\begin{array}{c}0.34 \\
(0.27)\end{array}$ & $\begin{array}{c}0.13 \\
(0.29)\end{array}$ & $\begin{array}{c}0.24 \\
(0.33)\end{array}$ & \\
\hline Congressional Policy Product ${ }^{\star}$ Top Share ${ }_{t-1}$ & $\begin{array}{l}-0.01^{\star *} \\
(0.00)\end{array}$ & $\begin{array}{l}-0.01^{\star} \\
(0.00)\end{array}$ & $\begin{array}{l}-0.01^{* * *} \\
(0.00)\end{array}$ & $\begin{array}{l}-0.01^{\star} \\
(0.00)\end{array}$ & $\begin{array}{l}-0.01^{\star} \\
(0.00)\end{array}$ \\
\hline House Party Polarization ${ }^{\star}$ Top Share $_{t-1}$ & $\begin{array}{l}-3.00^{\star * *} \\
(0.90)\end{array}$ & $\begin{array}{l}-2.18^{\star *} \\
(1.07)\end{array}$ & $\begin{array}{l}-3.57^{* * *} \\
(1.31)\end{array}$ & $\begin{array}{l}-3.32^{\star *} \\
(1.29)\end{array}$ & $\begin{array}{l}-2.30^{* * *} \\
(0.76)\end{array}$ \\
\hline$\Delta$ Democratic Senate $_{t}$ & & $\begin{array}{l}-0.75 \\
(0.59)\end{array}$ & & & \\
\hline Democratic Senate $_{t-1}$ & & $\begin{array}{l}-0.68 \\
(0.44)\end{array}$ & & & \\
\hline$\Delta$ Democratic House $_{t}$ & & $\begin{array}{c}0.48 \\
(0.69)\end{array}$ & & & \\
\hline Democratic House $_{t-1}$ & & $\begin{array}{c}0.11 \\
(0.50)\end{array}$ & & & \\
\hline$\Delta$ Top Capital Gains Tax Rate ${ }_{t}$ & & & $\begin{array}{l}-0.04 \\
(0.05)\end{array}$ & & \\
\hline Top Capital Gains Tax Rate ${ }_{t-1}$ & & & $\begin{array}{l}-0.04 \\
(0.04)\end{array}$ & & \\
\hline$\Delta$ Top Marginal Tax Rate ${ }_{t}$ & & & $\begin{array}{l}-0.02 \\
(0.03)\end{array}$ & & \\
\hline Top Marginal Tax Rate ${ }_{t-1}$ & & & $\begin{array}{l}-0.06^{\star \star} \\
(0.02)\end{array}$ & & \\
\hline$\Delta$ Financial Deregulation $_{t}$ & & & $\begin{array}{l}1.50^{\star \star} \\
(0.65)\end{array}$ & & \\
\hline Financial Deregulation $_{t-1}$ & & & $\begin{array}{c}0.01 \\
(0.48)\end{array}$ & & \\
\hline$\Delta$ Prime Rate $_{t}$ & & & $\begin{array}{l}-0.48^{\star \star} \\
(0.18)\end{array}$ & & \\
\hline Prime Rate ${ }_{t-1}$ & & & $\begin{array}{l}-0.25^{\star \star} \\
(0.11)\end{array}$ & & \\
\hline$\Delta$ Financial Profits, $\% \mathrm{GDP}_{t}$ & & & & $\begin{array}{c}0.12 \\
(0.88)\end{array}$ & \\
\hline
\end{tabular}


TABle 1 (Continued)

(1)

Financial Profits, \% GDP $\mathrm{GD}_{t-1}$

$\Delta$ Union Membership Rate ${ }_{t}$

Union Membership Rate R-1 $_{t-1}$

$\Delta$ Real GDP Per Capita (2005 USD) ${ }_{t}$

Real GDP Per Capita (2005 USD) $)_{t-1}$

Constant

Observations

$R^{2}$

$(0.14)$

67

0.55
(2)

(3)

(4)

0.16

(0.56)

0.03

$(0.19)$

0.01

$(0.10)$

$-0.00$

$(0.00)$

0.00

(0.00)

$-1.03$

(3.37)

67

$(2.13)$

67

67

0.57

0.69

0.56
$0.30^{* *}$

$(0.14)$

67

0.48

Note: Prais-Winsten estimates with standard errors in parentheses. ${ }^{*} p<0.10 ;{ }^{* *} p<0.05 ;{ }^{* * *} p<0.01$; two-tailed tests.

primary effect of these variables is via the errorcorrection component of the model, which is captured in the coefficient for the lagged level of each variable. By interacting the status quo bias measures with the lagged level of top income shares, we directly test the idea that rising inequality has made status quo bias more important as an explanation of distributional outcomes.

In this initial model, we see support for aspects of the CSQB argument. The effect of the Senate Median to Filibuster-Pivot Distance is positive and significant, suggesting that as ideological distance between the median and filibuster-pivot Senators increases, inequality increases as well. Also, the long-run effect of Congressional Policy Product is negative, meaning that less policymaking is associated with more inequality. These are important results. Status quo bias corresponds with the proportion of income held by the richest 1\% of Americans. Furthermore, the interactions between these variables and past values of top income share are significant in the expected direction.

Since the status quo bias variables are each part of multiplicative interaction terms, the effects estimated are conditional on the value of inequality. The estimated main effect for each variable is its effect when inequality is at its mean value (since we mean-centered all variables prior to calculating interaction terms). To get a more complete sense of how the effect of the status quo bias variables change at differing levels of inequality, Figure 2 presents the marginal effects of the four variables included in this model at all observed values of top income share. The conditional effects of Filibuster-Pivot Distance and Congressional Policy Product are both consistent with the idea that status quo bias becomes more inequality-inducing as inequality rises. At high levels of inequality, the Filibuster-Pivot Distance has a strong and significant positive effect on inequality. Likewise at high levels of inequality, Congressional Policy Product has a negative relationship with inequality. While the interaction term for maximum ideological distance across policymaking branches is in the expected direction, it is not significant, and the effect of preference distance never reaches statistical significance at any level of inequality. These results are generally supportive of the argument that policy action is necessary to reduce inequality, that the institutional design of the U.S. policymaking system makes it difficult to produce such policy action, and that this status quo bias becomes increasingly important as inequality rises. ${ }^{17}$ These results also point

\footnotetext{
${ }^{17}$ While our primary purpose for including House Party Polarization is to ensure that the effect of Senate Filibuster-Pivot Distance is not driven by general polarization, we should note that the interactive effect of party polarization is at first blush not fully anticipated. The observed positive relationship in Figure 2 between polarization and top income share when inequality is low aligns with our expectations and the earlier bivariate results of McCarty, Poole, and Rosenthal (2006). But as inequality rises, after controlling for institutional status quo bias, the effect of party polarization becomes somewhat more egalitarian. We think this result may be explained by the fact that polarization in the House is not as disruptive to the policymaking process as the Filibuster-Pivot Distance in the Senate. This makes sense given the procedural capacity of the House majority to move legislation through the chamber quite efficiently (Cox and McCubbins 2005a), perhaps having even more ability to do so when party polarization is high (Aldrich and Rohde 2000). Furthermore, as we report in the Supporting Information, the indirect effect of house polarization (through Congressional Policy Product) implies that when inequality is high, the total effect of polarization is as expected.
} 


\section{FIgURE 2 Effect of Status Quo Bias at Observed Levels of Lagged Top Share}

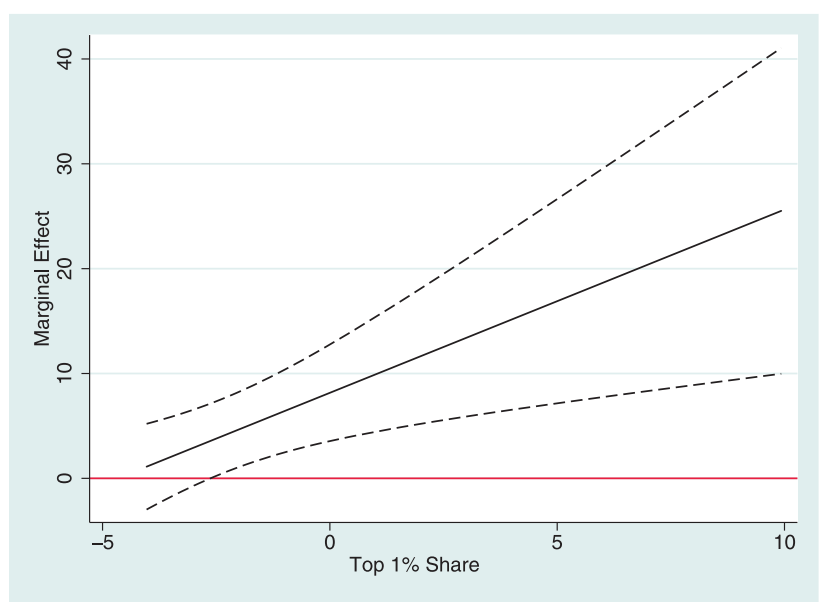

(a) Filibuster-Pivot Distance

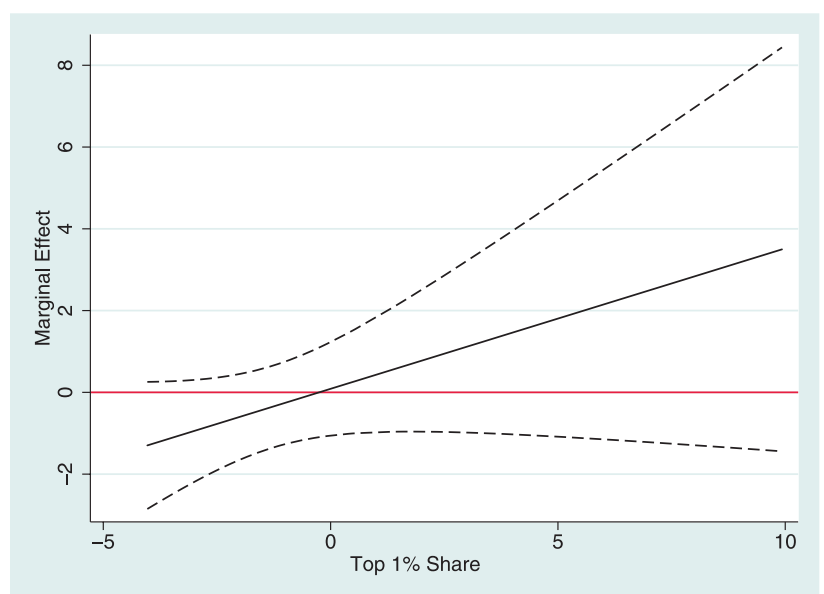

(c) Maximum Preference Distance

to the central role of the Senate in the U.S. governing system. It is status quo bias in the Senate that has the most consistent (conditional) effect on top income shares.

In Model 2, we control for partisan control of Congress. ${ }^{18}$ With controls for these partisan explanations of top income shares, the core results are similar, though some variables now fail to achieve statistical significance. However, the partisan variables have no effect on top shares when variables related to status quo bias are considered. Indeed, we cannot reject the null hypothesis that the combined influence of all partisan variables is different from zero

\footnotetext{
${ }^{18}$ Controlling for the party of the president does not substantially alter the substantive results reported here (see Table 4 in the Supporting Information file) but consistent with other work (Volscho and Kelly 2012) is not a predictor of top income shares so is excluded from these models.
}

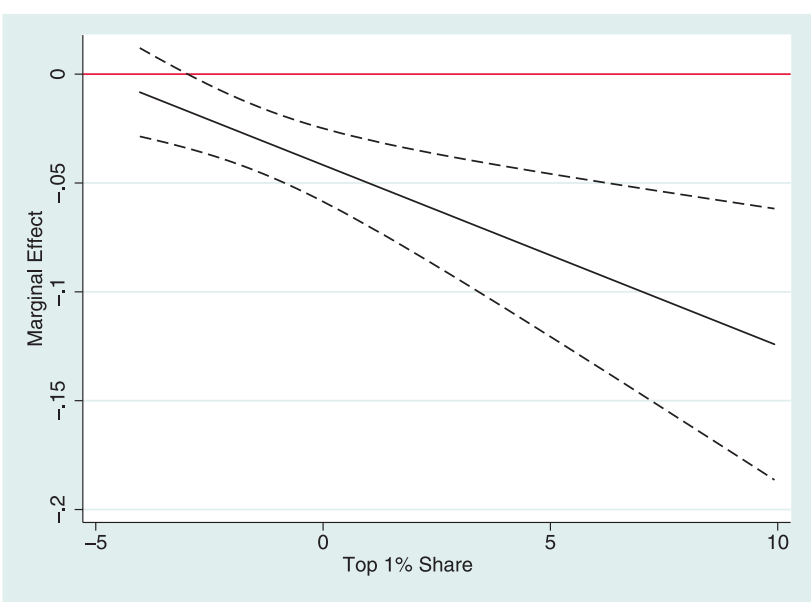

(b) Congressional Policy Product

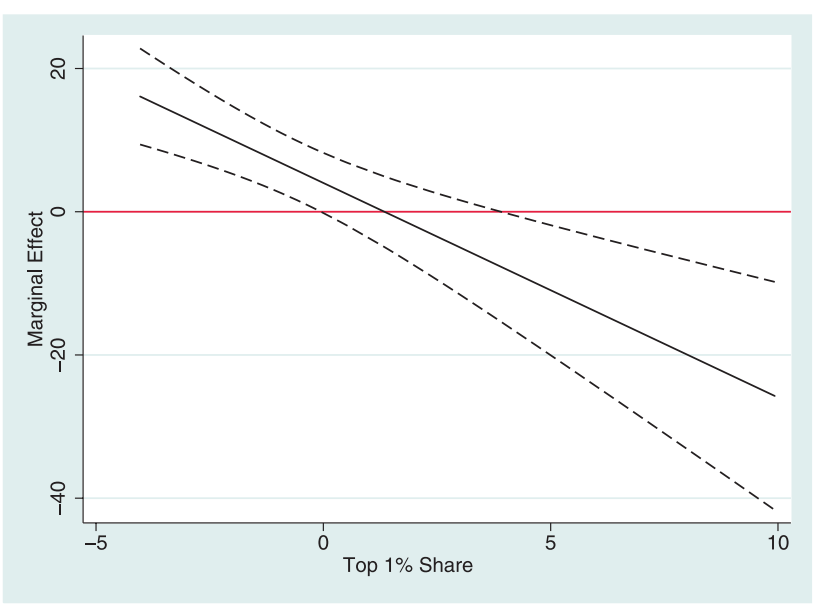

(d) Polarization

$(\mathrm{p}=0.52)$. Model 3 replaces partisan variables with policy variables. Again, the results for the status quo bias variables are quite similar to the initial model. We also see here that some of the policy variables have the expected relationships. The results suggest that increasing the top marginal tax rate decreases top income shares, with this effect occurring over the long term. Financial deregulation corresponds with greater income inequality, but this relationship occurs over the short term, having its full effect within a year. Increasing interest rates appears to affect top income shares in both the short and the long term, immediately decreasing top income shares and also having an egalitarian effect that is spread out over a longer period of time. In this model, long-term effects are felt at a rate of $43 \%$ each year, so it take several years to be fully observed. In Model 4, we include controls for social and economic conditions. With controls for general economic conditions, the shifting structure of 
Figure 3 Total Expected Shift in the Income Share of the Top 1\%

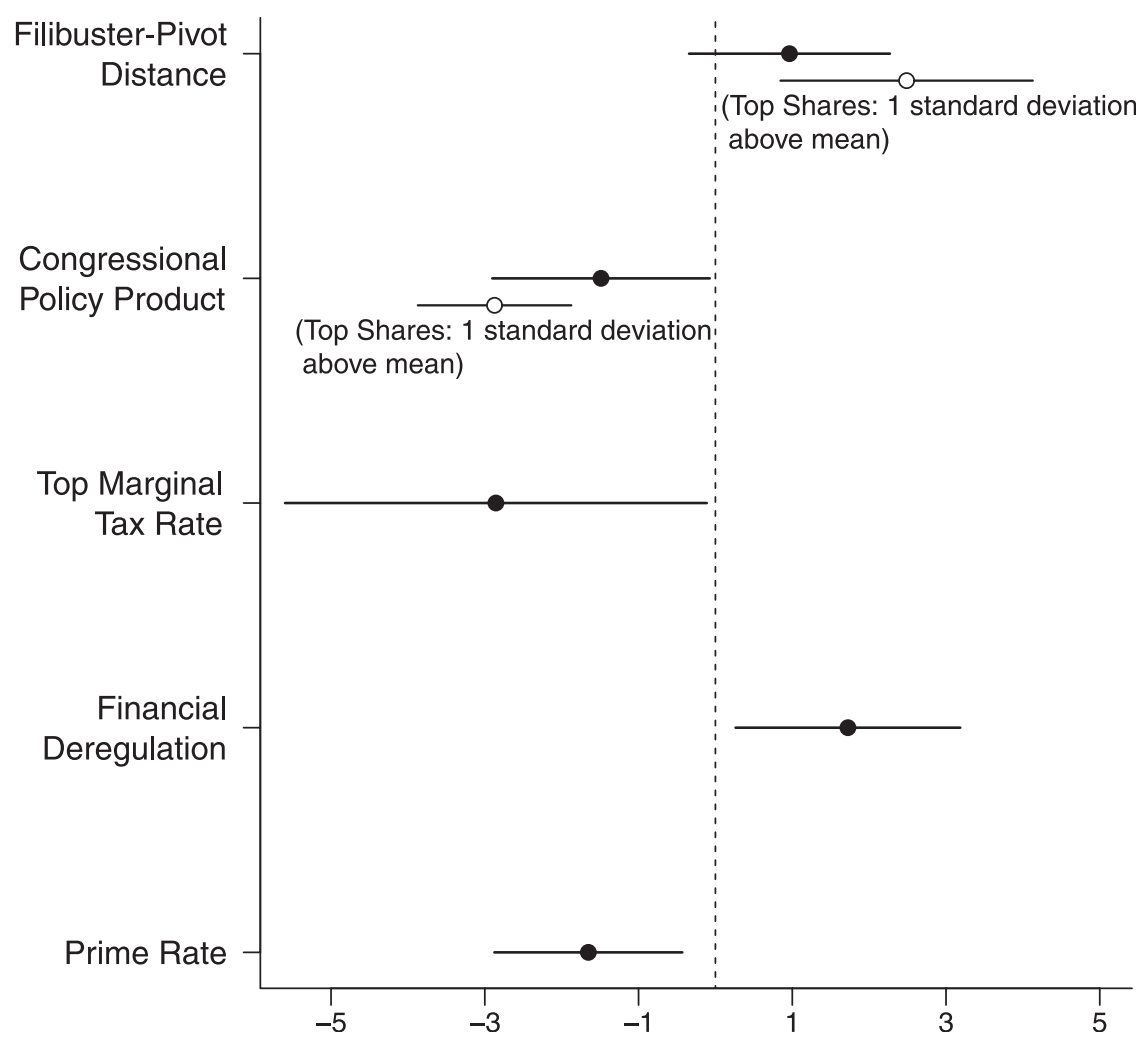

the economy toward finance, and the decline of unions, the results for our CSQB measures remain as reported in the initial model. Finally, in Model 5 we report an extremely parsimonious model that only includes variables related to status quo bias and polarization that were significant in earlier models. We do this to ensure that our core results are not somehow driven by overfitting, which is a potential concern here given the large number of coefficients estimated in the first four models. Again, the core results reported above hold.

To this point we have said little about the substantive effects of the variables in our model. As a first step in this direction, we should point out that the models we estimate explain a substantial amount of variance in over-time change in the share of income held by the top $1 \%$. The $R^{2}$ of the models are between 0.48 and 0.69 . More to the point, the statistically significant effects estimated above are quite large. In Figure 3, we chart the total expected shift (and 95 percent confidence interval) in top income shares (long-run or short-term as appropriate) produced by a standard deviation shift in the key explanatory variables from Model 3. Because the estimates for Filibuster-Pivot Distance and Congressional Policy
Product are conditional on the past value of top income share, we report two estimates for these variables. The solid dot represents the total expected effect at the mean value of top income share. The hollow dot corresponds with the total expected effect when the proportion of income held by the top $1 \%$ is one standard deviation above the mean value. The figure indicates that when income is concentrated among the top $1 \%$ at a level one standard deviation above the average from the last 70 years, then Filibuster-Pivot Distance, Congressional Policy Product, and top marginal tax rates have expected effects of a similar magnitude. Financial deregulation and monetary policy have smaller but still important effects. Even a one percentage point shift in top income shares is extremely important because such a shift represents billions of dollars in the contemporary U.S. economy.

The results generally support our theory of CSQB. But it is interesting to note that not all indicators of status quo bias have the expected effect. None of the models estimated above point to an effect for preference divergence across institutions. This null result holds in a variety of specifications, including models excluding Congressional Policy Product. This suggests 
that the Senate is a central player in the U.S. policymaking system. It may be that polarization in the Senate is the most dramatic contributor to status quo bias. And this is to some extent anticipated by those previously making theoretical arguments similar to ours (Stepan and Linz 2012). Importantly, as we report in the Supporting Information and Footnote 10, House Polarization does appear to indirectly influence top shares by affecting Congressional Policy Product. It is also worth noting that the effects of status quo bias are generally felt over a long period of time. In the models that focus most specifically on variables related to status quo bias, we see error correction rates of 0.18 and 0.19 , meaning that the longrun effect of these variables are realized at a rate of only about $19 \%$ per year. When policy agreement becomes harder in the Senate and policy production declines, the effects persist years into the future.

\section{Conclusion}

The analysis above makes both an empirical and theoretical contribution to our understanding of U.S. income inequality. We considered how status quo bias in the American governing system could help explain changes in inequality over time. On this front, we have built on previous analysis rooted in qualitative evidence (Hacker and Pierson 2010) and time-series analysis that is primarily bivariate in nature (McCarty, Poole, and Rosenthal 2006). Here, we utilized quantitative time-series analysis that shows evidence of an effect of status quo bias on top income shares while controlling for other political and socioeconomic variables. We also went beyond previous studies by specifying a conditional theory of status quo bias in which the inequality-inducing effect of status quo bias is magnified when existing levels of inequality are high.

The primary conclusion of our analysis is that the status quo bias created by the design of American policymaking institutions has contributed to rising inequality. As Stepan and Linz (2012) have recently argued, the comparative literature suggests that the high inequality in the United States compared to other developed democracies can be explained in part by unique aspects of the U.S. system, such as the disproportionate power of the Senate, the malapportionment of the Senate, the existence of the filibuster, and the high number of veto points. We found evidence suggesting that some of these factors have contributed to the increase in top income shares over time. As the distance between the median Senator (the pivotal voter in a purely majoritarian institution), and the filibuster pivot (the pivotal voter under the current Senate rules) increases, inequality increases as well. It is particularly hard to shift policy from the status quo in the United States. When Congressional Policy Product decreases and policy "drifts" (Hacker and Pierson 2010), inequality appears to rise. Even after controlling for policy factors like the top marginal tax rate and financial deregulation, status quo bias matters for inequality. Although many factors may lead to rising inequality, status quo bias makes this process difficult to reverse. Importantly, we find evidence that the effects of variables related to institutionalized status quo bias become larger at higher levels of income concentration, which provides additional evidence that the effect of stalemate matters more as conditions favorable to rising inequality emerge and intensify. However, while we suggested that both economic and political processes can sustain rising inequality when status quo bias is high, our analysis does not consider which may be more important. We hope future research will disentangle these two pathways that likely make status quo bias more inequality inducing as levels of inequality increase.

Future research could also further explore the CSQB we have uncovered. During the 70 years following the Great Depression, we observe a substantial relationship between shifting levels of status quo bias and inequality. Yet, the last decade has witnessed the highest levels of inequality and filibuster pivot distance in our period of study and the lowest levels of Congressional policy product. It will be important to study the conditional nature of status quo bias as conditions continue to change.

Recent work in American politics has given some reason to believe that changing the distribution of income in the United States can be achieved through the democratic political process. Electing different leaders has implications for inequality (Bartels 2008; Kelly 2009; Volscho and Kelly 2012). Pursuing different policies shapes the distribution of income (Hacker and Pierson 2010; Kelly 2005; Volscho and Kelly 2012). Furthermore, the policies needed to reduce inequality are not all in the realm of traditional redistribution. The market itself can be shaped by governmental decisions, and leveling the playing field with regard to opportunity is likely to level the final tally of income. However, our analysis indicates that the U.S. institutional context obstructs policy efforts that might fundamentally alter income concentration in the face of current economic conditions. The evidence here indicates that the filibuster has likely prevented policy changes that would reduce inequality. In fact, when we control for variables related to status 
quo bias, we found that partisan control of policymaking institutions adds almost no additional explanatory power. Given these findings and the current political environment in Congress, the significant changes to policy that may be required in order to substantially alter distributional outcomes would appear challenging to enact without institutional reform.

\section{Acknowledgments}

We appreciate comments on previous versions of this article from Chuck Finocchiaro, Jacob Hacker, Evelyne Huber, John Stephens, Caroline Tolbert, three anonymous reviewers, and the Texas A\&M University, University of Connecticut, and University of Pittsburgh political science departments. Remaining errors are solely the responsibility of the authors.

\section{References}

Aldrich, John H., and David W. Rohde. 2000. "The Consequences of Party Organization in the House: The Role of the Majority and Minority Parties in Conditional Party Government." In Polarized Poliitcs: Congress and the President in a Partisan Era, ed. Jon R. Bond and Richard Fleisher. Washington, DC: CQ Press, 31-72.

Alesina, Alberto, and Edward Glaeser. 2004. Fighting Poverty in the US and Europe: A World of Difference. New York: Oxford University Press.

Banerjee, Anindya, Juan Dolabo, John Galbraith, and David F. Hendry. 1993. Co-integration, Error Correction, and the Econometric Analysis of Non-stationary Data. New York: Oxford University Press.

Bartels, Larry M. 2008. Unequal Democracy: The Political Economy of a New Gilded Age. Princeton, NJ: Princeton University Press.

Baumgartner, Frank R., and Bryan D. Jones. 2010. Agendas and Instability in American Politics. Chicago: University of Chicago Press.

Binder, Sarah. 2003. Stalemate: The Causes and Consequences of Legislative Gridlock. Washington, DC: Brookings Institution Press.

Binder, Sarah A., and Steven S. Smith. 1997. Politics or Principle?: Filibustering in the United States Senate. Washington, DC: Brookings Institution Press.

Birchfield, Vicki. 2008. Income Inequality in Capitalist Democracies: The Interplay of Values and Institutions. State College, PA: Penn State University Press.

Bradley, David, Evelyne Huber, Stephanie Moller, François Nielsen, and John Stephens. 2003. "Distribution and Redistribution in Post-Industrial Democracies." World Politics 55 (2): 193-228.

Brady, David W., and Craig Volden. 1998. Revolving Gridlock: Politics and Policy from Carter to Clinton. Boulder, CO: Westview Press.

Bureau of Economic Analysis. 2012. "Gross Domestic Product by Industry Data." Technical report available at http://www.bea. gov/industry/gdpbyind_data.htm.
Campbell, James E. 2011. "The Economic Records of the Presidents: Party Differences and Inherited Economic Conditions." The Forum: A Journal of Applied Research in Contemporary Politics 9 (1): Article 7.

Canterbery, E. Ray. 2002. "The Theory of the Bondholding Class." Lournal of Economic Issues 36 (2): 365-72.

Carroll, Royce, Jeff Lewis, James Lo, Nolan McCarty, Keith Poole, and Howard Rosenthal. 2011. "“Common Space" DW-NOMINATE Scores With Bootstrapped Standard Errors (Joint House and Senate Scaling)." http://voteview. com/dwnomin_joint_house_and_senate.htm.

Charemza, Wojciech W., and Derek F. Deadman. 1992. New Directions in Econometric Practice: General to Specific Modeling, Cointegration, and Vector Autoregression. Northampton, MA: Edward Elgar.

Cox, Gary W., and Mathew D. McCubbins. 2005a. Legislative Leviathan: Party Government in the House. 2nd ed. New York: Cambridge University Press.

Cox, Gary W., and Mathew D. McCubbins. 2005b. Setting the Agenda: Responsible Party Government in the US House of Representatives. New York: Cambridge University Press.

Crepaz, Markus M. L. 2001. "Veto Players, Globalization and the Redistributive Capacity of the State: A Panel Study of 15 OECD Countries." Iournal of Public Policy 21 (1): 1-22.

Davidson, Russell, and James G. MacKinnon. 1993. Estimation and Inference in Econometrics. New York: Oxford University Press.

Demenil, Gerard, and Dominique Levy. 2004. Capital Resurgent: Roots of the Neoliberal Revolution. Cambridge, MA: Harvard University Press.

Engle, Robert F., and Clive W. J. Granger. 1987. "Co-Integration and Error Correction: Representation, Estimation, and Testing." Econometrica 55 (2): 251-76.

Finocchiaro, Charles J., and David W. Rohde. 2008. "War for the Floor: Partisan Theory and Agenda Control in the US House of Representatives." Legislative Studies Quarterly 33 (1): 35-61.

Gailmard, Sean, and Jeffery A Jenkins. 2007. "Negative Agenda Control in the Senate and House: Fingerprints of Majority Party Power." Lournal of Politics 69 (3): 689-700.

Gilens, Martin. 2012. Affluence and Influence: Economic Inequality and Political Power in America. Princeton, NJ: Princeton University Press and Russell Sage Foundation.

Grant, J. Tobin, and J. Kelly Nathan. 2008. "Legislative Productivity of the U.S. Congress, 1789-2004." Political Analysis 16 (3): 303-23.

Hacker, Jacob S., and Paul Pierson. 2010. Winner-Take-All Politics. New York: Simon \& Schuster.

Hacker, Jacob, Suzanne Mettler, Dianne Pinderhughes, and Theda Skocpol. 2004. "Inequality and Public Policy." Report for the Task Force on Inequality and American Democracy: American Political Science Association.

Henwood, Doug. 1997. Wall Street: How It Works and for Whom. Ithaca, NY: Cornell University Press.

Hibbs, Douglas A., Jr., and Christopher Dennis. 1988. "Income Distribution in the United States." American Political Science Review 2 (2): 467-89.

Hicks, Alexander M. 1999. Social Democracy and Welfare Capitalism. Ithaca, NY: Cornell University Press.

Hirsch, Barry T. 2008. "Sluggish Institutions in a Dynamic World: Can Unions and Industrial Competition Coexist?" Iournal of Economic Perspectives 22 (1): 153-76. 
Huber, Evelyne, Charles Ragin, and John D. Stephens. 1993. "Social Democracy, Christian Democracy, Constitutional Structure and the Welfare State." American Journal of Sociology 99 (3): 711-49.

Huber, Evelyne, and John D. Stephens. 2001. Development and Crisis of the Welfare State. Chicago: The University of Chicago Press.

Huber, Evelyne, and John D. Stephens. 2006. "Combating Old and new Social Risk." In The Politics of Post-Industrial Welfare States, ed. Klaus Armingeon and Guiliano Bonoli. New York: Routledge, 143-68.

Kaplan, Steve, and Joshua Rauh. 2010. "Wall Street and Main Street: What Contributes to the Rise in the Highest Income." Review of Financial Studies 23 (3): 1004-50.

Katznelson, Ira. 2013. Fear Itself: The New Deal and the Origins of Our Time. New York: Liveright.

Keele, Luke, and Nathan J. Kelly. 2006. "Dynamic Models for Dynamic Theories: The Ins and Outs of Lagged Dependent Variables." Political Analysis 14 (2): 186-205.

Kelly, Nathan J. 2005. "Political Choice, Public Policy, and Distributional Outcomes." American Journal of Political Science 49 (4): 865-80.

Kelly, Nathan J. 2009. The Politics of Income Inequality in the United States. New York: Cambridge University Press.

Kelly, Nathan J., and Christopher Witko. 2012. "Federalism and American Inequality." The Journal of Politcs 74 (2): 414-26.

Kelly, Nathan J., and Peter K. Enns. 2010. "Inequality and the Dynamics of Public Opinion: The Self-Reinforcing Link Between Economic Inequality and Mass Preferences." American Journal of Political Science 54 (5): 855-70.

Kenworthy, Lane. 2010. "How Much do Presidents Influence Income Inequality?" Challenge 53 (2): 90-112.

Koger, Gregory. 2010. Filibustering: A Political History of Obstruction in the House and Senate. Chicago: University of Chicago Press.

Korpi, Walter. 1978. The Working Class in Welfare Capitalism: Work, Unions, and Politics in Sweden. London: Routledge and Kegan Paul.

Krehbiel, Keith. 1998. Pivotal Politics: A Theory of U.S. Lawmaking Chicago: University of Chicago Press.

Krippner, Greta. 2011. Capitalizing on Crisis. Cambridge, MA: Harvard University Press.

McCarty, Nolan, Keith Poole, and Howard Rosenthal. 2006. Polarized America: The Dance of Ideology and Unequal Riches. Cambridge, MA: MIT Press.

McCubbins, Mathew D., and Thomas Schwartz. 1984 "Congressional Oversight Overlooked: Police Patrols versus Fire Alarms." American Journal of Political Science 28 (1): 165-79.

Moller, Stephanie, David Bradley, Evelyne Huber, François Nielsen, and John D. Stephens. 2003. "Determinants of Relative Poverty in Advanced Capitalist Democracies." American Sociological Review 68 (1): 22-51.

Morgan, Jana, and Nathan J Kelly. 2013. "Market Inequality and Redistribution in Latin America and the Caribbean." Iournal of Politics 3 (3): 672-85.
Philippon, Thomas, and Ariell Reshef. 2012. "Wages and Human Capital in the US Finance Industry: 1909-2006." The Ouarterlv Journal of Economics 127 (4): 1551-1609.

Pierson, Paul. 2000. "Increasing Returns, Path Dependence, and the Study of Politics." American Political Science Review 94 (2): 251-67.

Piketty, Thomas, and Emmanuel Saez. 2003. "Income Inequality in The United States, 1913-1998." Quarterly Journal of Economics 118 (1): 1-39.

Richman, Jesse. 2011. "Parties, Pivots, and Policy: The Status Quo Test." American Political Science Review 105 (1): 151-65.

Slemrod, Joel. 1996. "High Income Families and the Tax Changes of the 1980s: The Anatomy of a Behavioral Response." In Empirical Foundations of Household Taxation, ed. Martin Feldstein and James M. Poterba. Chicago: University of Chicago Press, 169-92.

Stepan, Alfred, and Juan J. Linz. 2012. "Comparative Perspectives on Inequality and the Quality of Democracy in the United States." Perspectives on Politics 9 (4): 841-56.

Stephens, John D. 1979. The Transition from Capitalism to Socialism. London: Macmillan.

Tomaskovic-Devey and Ken-Hou Lin. 2011. "Income Dynamics, Economic Rents, and the Financialization of the U.S. Economy." American Sociological Review 76 (4): 538-59.

Tsebelis, George. 2002. Veto Plavers: How Political Institutions Work. Princeton, NJ: Princeton University Press.

Volscho, Thomas W., and Nathan J. Kelly. 2012. "The Rise of the Super-Rich: Power Resources, Taxes, Financial Markets, and the Dynamics of the Top 1 Percent, 1949-2008." American Sociological Review 77 (5): 679-99.

Wawro, Gregory John, and Eric Schickler. 2006. Filibuster: Obstruction and Lawmaking in the US Senate. New York: Cambridge Universty Press.

Peter K. Enns is an Assistant Professor in the Department of Government at Cornell University, Ithaca, NY 14850.

Nathan J. Kelly is an Associate Professor in the Department of Political Science at the University of Tennessee, Knoxville, TN 37996.

Jana Morgan is an Associate Professor in the Department of Political Science at the University of Tennessee, Knoxville, TN 37996.

Thomas Volscho is an Assistant Professor in the Departments of Sociology, Anthropology, and Social Work at City University of New York, Staten Island, NY 10314.

Christopher Witko is an Associate Professor in the Department of Political Science at the University of South Carolina, Columbia, SC 29208. 